\title{
The challenge of comparing EU Member States judicial data
}

OÑati SOCiO-Legal Series Volume 11, Issue 2 (2021), 446-480: “ToO Much Litigation?”: Facts, REASONS, CONSEQUENCES, AND SOLUTIONS

DOI LINK: HTTPS://DOI.ORG/10.35295/OSLS.IISL/0000-0000-0000-1151

RECEIVED 23 SEPTEMBER 2019, ACCEPTED 01 SEPTEMBER 2020

\author{
ELENA ALINA ONȚANU* (D) \\ MARCO VELICOGNA* ID
}

\section{Abstract}

The number of cases is measured through a broad range of quantitative variables used in various studies and policy papers as key indicators of the volume of activity of national courts. Additionally, these variables, together with other data (e.g. time needed to resolve a case, number of judges, etc.) are part of a broader discourse on the efficiency of justice systems. However, such discourse can be problematic when data is not actually comparable. To raise the attention on this very relevant but poorly explored topic, this paper analyses the comparability of the caseload data by focusing on apparently simple categories like civil and commercial litigious or non-litigious cases and administrative cases. The EU Justice Scoreboard and CEPEJ data and national case definitions in France, Italy, and Romania are used to assess the most relevant justice EU datasets. The findings point towards significant differences between analysed systems that suggest extreme caution should be exercised when using such data for scholarly, legislative or policy discourses.

\section{Key words}

EU Justice Scoreboard; CEPEJ data; comparability of datasets; courts' caseload; categories of cases

\section{Resumen}

El número de casos se mide mediante una amplia gama de variables cuantitativas que se utilizan en varios estudios y documentos de política como indicadores claves del volumen de actividad en tribunales nacionales. Además, esas variables, junto con otros

\footnotetext{
* Dr. Elena Alina Onțanu, Assistant Professor of Private International Law, Erasmus University Rotterdam. Erasmus University Rotterdam, Erasmus School of Law, L7.09, P.O. Box 1738, 3000 DR Rotterdam, The Netherlands. Email address: ontanu@law.eur.nl,

* Marco Velicogna, Researcher, Institute of Legal Informatics and Judicial Systems of the National Research Council of Italy (IGSG-CNR). Via Zamboni 26, 40126, Bologna (BO), Italy. Email address: marco.velicogna@cnr.it
} 
datos (por ej., tiempo que se ha necesitado para resolver un caso, número de jueces, etc.), son parte de un discurso más amplio sobre la eficacia de los sistemas judiciales. Sin embargo, ese discurso puede ser problemático cuando los datos no son comparables. Para llamar la atención sobre este tema, tan importante como poco explorado, este artículo analiza la comparabilidad de los datos sobre la carga de trabajo. Para ello, se centra en categorías aparentemente sencillas, como casos litigiosos o no litigiosos civiles y comerciales, y casos administrativos. Se utilizan los datos del indicador de la justicia de la UE y de la CEPEJ y definiciones de casos nacionales de Francia, Italia y Rumanía para evaluar los conjuntos de datos más importantes de la UE. Los hallazgos apuntan a diferencias significativas entre los sistemas analizados, las cuales hacen pensar que se deben utilizar esos datos con la máxima cautela ya sea en discursos académicos, legislativos o políticos.

\section{Palabras clave}

Indicadores de justicia de la UE; datos de la CEPEJ; comparabilidad de datos; carga de trabajo judicial; categorías de casos 


\section{Table of contents}

1. Introduction

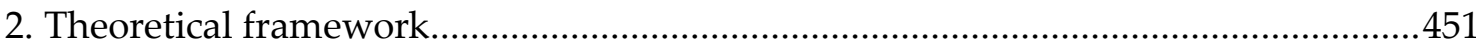

3. A critical analysis of the methodology behind EU justice data collection ..................453

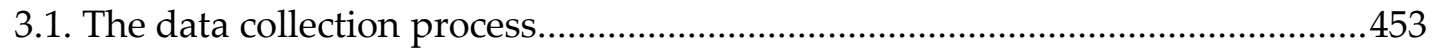

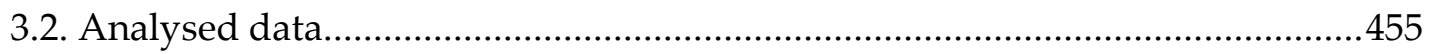

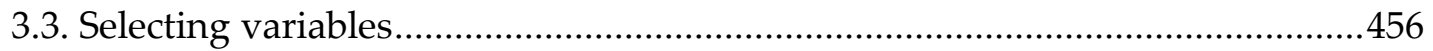

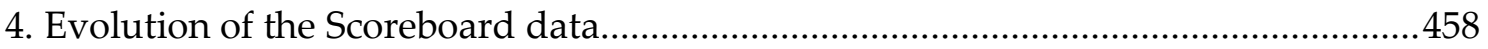

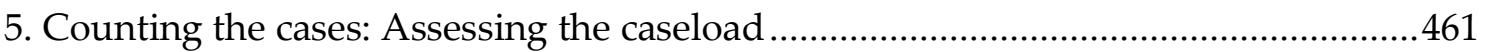

6. Exploring the (in)consistencies of the Scoreboard and national case categories to

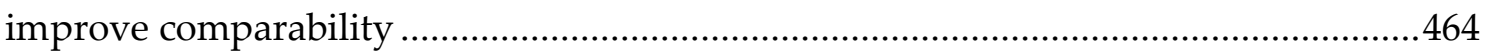

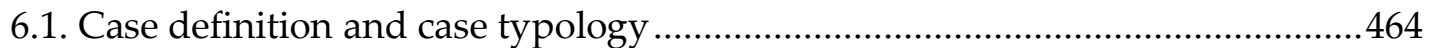

6.2. Data inconsistency: Identifying the causes in the CEPEJ Report ......................466

6.3. Consequences of inconsistencies in case categories ..........................................473

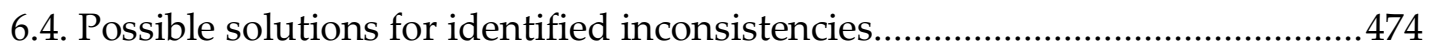

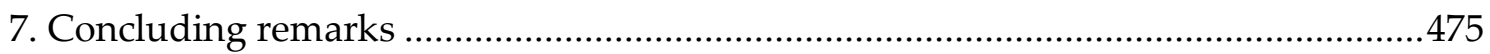

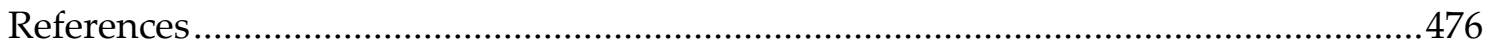




\section{Introduction}

The administration of justice has been progressively taking an increasingly significant role in democratic societies. The growing complexity of social relations, the development of the welfare state, the increasing cross-border mobility of people and the globalisation of trade relations have contributed to "the expansion of the judicial system and raised the quality and complexity of legal actions to be dealt with by the judiciary" (Velicogna and Ng 2006, p. 371). During the last decades, "there has been an increase in all kinds of cases, civil, family, penal, and administrative, in most European countries" (Fabri and Langbroek 2000; see also Koeijers 2005). With this increase in the activity of the judiciary since the 1990s - which is associated to a limitation of the resources to be allocated and a growing attention towards the efficiency and accountability of the public administration (i.e. diffusion of New Public Management theory) - the number of cases has become a critical component of the national discourse on the functioning of the courts and the resources they need. In national as well as international discussions on the efficiency of justice systems, regardless of the model chosen or legal tradition, several parameters such as the length of proceedings, the number of pending cases, ${ }^{1}$ and the capacity of courts to deal with the caseload have come to occupy centre stage (European Commission for the Efficiency of Justice - hereinafter, CEPEJ - 2018a, p. 237). At the individual level, quantitative data such as the number of incoming, ${ }^{2}$ pending and resolved cases, ${ }^{3}$ the length of proceedings and backlog ${ }^{4}$ has been used both to allow judges to monitor better their work and more actively manage their cases, including the creation of automated warning systems for approaching deadlines, and to evaluate their performance, as judges are increasingly "called not just to adjudicate, but also to manage cases" (Contini et al. 2017, p. 17). For example, in Finland, the judges' "statistical evaluation is based on the reports acquired from the case management system (e.g. number of solved cases, handling times of solved cases, number of pending cases, number of old pending cases)". Additionally, management team meetings are held to "ensure that the workload is even between the judges", to assess the reasons behind the large differences and to "ensure that the times from filing to hearing/handling of the cases are as equal as possible" (Pekkanen et al. 2017, p. 36). Further, the quantitative data on caseload has been used as a drive for the re-distribution of human resources between courts. After 2012, for example, the Hungarian judicial administration put a "heavy emphasis on the goal of ensuring a balanced workload for judges" (Bencze et al. 2017, p. 155), observing that "there were courts where judges had to deal with over two and the half times more incoming cases than judges serving at other courts" (Bencze et al. 2017, p. 152). In several countries quantitative data on the caseload and workload are also used for budgetary purposes. In France for example, the "allocation of budgetary resources is based on indicators and performance targets set by the Ministry" based on data such as the average time required to process civil and criminal proceedings, the number of cases

\footnotetext{
1 The "pending cases" are cases which have not been completed within a given period. See CEPEJ 2017, p. 19.

2 The "incoming cases" are all cases submitted to a court (first instance, second instance or Supreme Court) for the first time within the reference year. See CEPEJ 2017, p. 19.

3 The "resolved cases" include all the procedures which have come to an end at the level considered (first instance, appeal or Supreme Court if applicable) during the year of reference, either through a judgment or through any other decision which ended the procedure. See CEPEJ 2017, p. 19.

${ }^{4}$ The "backlog" represents the number of cases which duration exceeded a certain time standard.
} 
handled by judges and prosecutors, rates of annulment, etc. (Pauliat et al. 2017, p. 100). In Finland the budget and the performance targets for the courts are drafted every year by the Ministry of Justice and negotiated with the courts based on quantitative data. ${ }^{5}$ The Ministry then monitors the achievement of the operational targets set in the negotiations after six months and in the next negotiation (Pekkanen et al. 2017, pp. 3941). While the increasing attention to quantitative data has provided many useful elements to improve the overall quality of the justice service, it also presents several problems as it often reflects on a lower quality of judgements, increasing stress for judges, and a focus on simple cases (Fabri and Langbroek 2000, Contini and Mohr 2008, Contini et al. 2014, Contini 2017).

The national interest in measuring the number of cases the courts receive and can handle has also gained international attention. Several international organisations are following and evaluating judicial systems and measuring their quantitative results (e.g. World Bank work on Justice and Rule of Law and index on the quality of judicial systems, OECD actions related to Access to Justice data). At European level, the first evaluations of national legal systems began in the early 2000s. The Council of Europe established the European Commission for the Efficiency of Justice (CEPEJ) acknowledging the importance of fair, efficient and accessible justice systems as a requirement to guarantee the rule of law. Following the example of the CEPEJ, the European Commission launched its evaluation instrument in 2013. The EU Justice Scoreboard ("the Scoreboard") aims to help the Member States to improve the efficiency of their justice systems. Since the launch of the EU Justice Scoreboard in 2013, the CEPEJ has been gathering data for the European Commission initiative on several topics among which the number of judges and court staff, the caseload, and the length of court proceedings at various stages. In this efficiency of judiciary and national justice systems discourse, the number of cases the courts manage to handle and the timeframe within which this happens occupy centre stage.

Building on and updating the research carried out by Onţanu, Velicogna and Contini and published in How many cases? Assessing the comparability of EU Judicial datasets (Onțanu et al. 2018), this paper carries out an in-depth analysis of the quantitative variables the CEPEJ and the European Commission adopted as indicators of the volume of activity the national courts carry out: namely, the number of cases. These variables in conjunction with others (e.g. time needed to resolve cases) are part of the discourse on the efficiency of justice. This discourse has its origin in the increased relevance of business administration concepts and tools in the organisation and management of court activities.

The paper investigates how the data provided by the Member States to fill in simple categories of cases like civil and commercial litigious or non-litigious cases and administrative cases vary both across countries and over time, making a comparison at least problematic over time and across justice systems. The analysis deals with the comparability of these data. It shows that the comparability of the amount of litigation

\footnotetext{
${ }^{5}$ More in detail, a "weighted caseload system in use, where the different case groups have a weighted score depending on the complexity and time/resource requirements. In this system, the case categories are divided into different complexity categories based on the approximate time they require" (Pekkanen et al. 2017, p. 41).
} 
courts in various justice systems handle cannot be taken for granted and that a summarised data approach can bring with it subjective interpretations and invisible traps (see also Strelkov 2019, pp. 22-23). The definition of what a "case" is, as well as of the different "case types" and their status (i.e. open, closed, suspended, incoming, pending, and resolved) may differ quite consistently across countries (see also Onțanu et al. 2018). This makes the number of cases that are being handled by courts and the corresponding timeframe relative. Furthermore, this can also relativize the potential problem that high volumes of litigation might represent for national justice systems. What is to be considered a high amount of litigation? Is this problematic per se or only when correlated with other factors (e.g. resources, backlog)?

The paper is structured in seven parts. Section 2 discusses the theoretical framework. The methodology aspects concerning the EU dataset collection and analysis, as well as the selection of variables related to the volume of litigation to be analysed are addressed in Section 3. The consistency of the data is verified across historical series and through the analysis of documents that rely on the same data collection sources. Section 4 provides an overview of the evolution of the Scoreboard data. Section 5 analyses of the variables that are used by the Scoreboard to create an image of the caseload of courts and assesses their sufficiency. Section 6 examines in a selection of Member States - Italy, France, and Romania - what is considered to be a case according to their procedures, the typologies of cases and how they are fitted in the case categories that are part of the Scoreboard evaluation. The analysis explores, in particular, the consistency of case categories and historical data series, and the consequences that these inconsistencies can have for the evaluation of the analysed justice systems. Possible solutions to deal with the identified deficiencies are explored before concluding on the findings of this analysis. Section 7 sums up on the comparability of the data and the variables presenting the volume of cases national courts deal with according to the Scoreboard and the documents supporting it.

\section{Theoretical framework}

In this paper, we investigate the comparability of the key quantitative data provided by the European Commission about the number of cases. In carrying out the analysis, the paper explores the charts presented by the Scoreboard describing the courts' caseload and its variation. This is carried out to verify to what extent the data used in academic and political discourses based on such a collection of numbers is sound enough to make empirically grounded comparative (historical series or cross-countries) statements or whether the data needs to be seen in a more contextual and flexible framework. Previous analyses suggest that the comparability of such data is problematic in many areas, particularly the consistency of the answers across time (at the state level), and between countries within the same period (Uzelac 2012, Palumbo et al. 2013, Velicogna 2013, 2015, Fabri 2017). Any attempt to make cross-country comparisons should rely on comparable datasets that are used for the exercise (see, for example, Ietswaart 1990). If this essential condition is not respected, judicial reform, policies, and the growing body of studies based on initiatives such as the Scoreboard and the CEPEJ data should be seriously questioned.

In order to carry out this analysis of the Scoreboard and CEPEJ data collection comparability, the paper follows a two-step approach. The first step explores the process 
followed to collect the data analysing the methodology developed by the CEPEJ and the European Commission, looking both at the data collection and analysis and at the evolution of these instruments. This exploration started with an analysing of the existing literature on the topic (Uzelac 2012, Palumbo et al. 2013, Velicogna 2013, 2015, Mohr and Contini 2014, Dori 2015, Fabri 2017, Cappellina 2017, Strelkov 2019) and a mapping of the relevant documents forming the Scoreboard ecosystem (see Figure 1). The relevant documents have then been analysed taking into account the existing literature discussing them.

The second step of the process has consisted of an in-depth data consistency verification of the case categories and data collected in three justice systems: France, Italy and Romania. The choice of justice systems in which to carry out the verification was driven by a number of considerations. First, the authors have carried out extensive research on the justice systems examined, resulting in a deeper understanding of their functioning. Furthermore, the scholars' familiarity and knowledge of the justice systems analysed, and language competencies allowed them to have easy access to primary sources of information in the chosen jurisdictions, an aspect that would be very much limited when relying on indirect or secondary sources and materials. Additionally, the selection of countries characterized by similar institutional and procedural arrangements allows showing how problems of comparability of the data sets are not limited to countries with very different arrangements in civil, commercial and administrative law. The three systems belong to the Roman legal tradition. This characteristic contributes to a relatively homogenous choice and is meant to address some of the risks of overestimating differences and inconsistencies that are expected when comparing judicial systems belonging to different legal traditions (such as German or Nordic, or common law). The legal institutions in the area of civil, commercial and administrative matters, where the analysis has been focused, are to a considerable extent similar. This approach should bring the content of case law categories closer in terms of content rather than relying on more distant choices of systems where several outliers are expected. We decided, therefore, to focus "the analysis on comparable cases (i.e. cases that are similar in a large number of important characteristics, but dissimilar with regard to the variables between which a relationship is hypothesized)" (Lijphart 1975, p. 159). While possibly limiting the empirical generalisations of the findings, the observation of similar cases may also be more generative of feasible solutions which may more easily lead to the data comparability in clusters of justice systems. As Stretton suggests,

[r]ather than imitating experimental control, a more promising use of comparative study is to extend the investigator's experience, to make him aware of more possibilities and social capacities, and thus to help his imagination of question-prompting, causeseeking and effect-measuring alternatives, rational models, ideal types, utopias and other useful functions. The function of comparison is less to simulate experiment than to stimulate imagination. (Stretton 2013, pp. 245-246)

This is in line with the objectives of the paper, which aims not just to empirically test the comparability of the Scoreboard and CEPEJ data collection, but also to explore possible means of improvement.

The authors are aware that contextual factors, such as local practices, should be considered when analysing the flow of cases and better understanding courts caseload dynamics, and that these elements should be considered in addition to the ones explored 
in the present paper. At the same time, the impact of these elements on the comparability of statistical data without a better understanding of local context is left to future works, as they require an even more in-depth investigation than the one carried out so far and a more case study-oriented methodology.

\section{A critical analysis of the methodology behind EU justice data collection}

The authors recognise the effort undertaken both by the CEPEJ and by the European Commission to collect, analyse and provide data on the functioning of European Justice systems. In particular, the CEPEJ data collection effort, with its questionnaire of over 200 questions, many of which composed of several sub-questions, resulted in "a unique collection of data and information about the functioning of European judicial systems since 2004, which has no equal in any other study carried out by international organizations or researchers" (Fabri 2017, p. 619). At the same time, the "extraordinary laboratory of innovations and changes" (ibidem, p. 620) which results from the data collection from very different judicial systems are characterised by different organisational, procedural, legal and institutional settings. This, in turn, also generates much complexity in relation to the reliability and consistency of the data collected.

The work and analysis undertaken by the CEPEJ and subsequently by the European Commission and other organisations are highly dependent and conditioned ultimately by the quality and fragmentation of the data available at the national level in the Member States. For this reason, initiatives such as the European Commission Scoreboard and CEPEJ Studies have encouraged the Member States to collect additional data and statistics, as well as to progressively head towards a more homogenous data collection regarding judicial activities. ${ }^{6}$ In particular, over the years, the CEPEJ, in collaboration with the national correspondents, worked to develop an Explanatory Note which "has been drafted and periodically amended to assist the national correspondents" (CEPEJ $2012,2013,2015$ a) and in so doing to ensure that concepts are addressed according to a common understanding" (Fabri 2017, p. 620). While this effort is highly laudable, the question of comparability remains open, and in our perspective can be supported by a critical analysis of the methodology followed, in order to observe weaknesses and reflect on possible improvements.

\subsection{The data collection process}

The availability of data related to the number of cases handled by national courts that can be assembled in a comparative data set is difficult to obtain across legal systems. The data collected by the Member States and provided for the Biannual COE CEPEJ Study and the Annual EU CEPEJ Study are often gathered for domestic purposes and mirror differences in procedures and judicial organisation. ${ }^{7}$ Thus, the data are likely based on different categories and operational definitions than those of the CEPEJ (Mohr and Contini 2014, p. 8). The way the data are collected at the national level and reported for these European initiatives generates and maintains this difficulty of gathering

\footnotetext{
${ }^{6}$ On a discussion on the evolution of data methods used by CEPEJ and models of justice evaluations, see also Cappellina 2017.

${ }^{7}$ On a similar finding concerning the purpose of national official statistics, see Ietswaart 1990, p. 573, and Onțanu et al. 2018, p. 510.
} 
comparable data sets. The data related to the number of cases represent one of the pillars on which the EU Justice Scoreboard, the most important EU report on the functioning of European justice systems, is built on. In general, the EU Justice Scoreboard relies on various sources for its data (e.g. a group of contact persons on national justice systems designated by the Member States, the Network of the Presidents of the Supreme Judicial Courts of the EU, the Consumer Protection Cooperation Network, Eurostat). These other sources are not part of the present analysis. A large part of the statistical data, and in particular the data relevant for the present analysis are provided by the CEPEJ with which the European Commission concluded an agreement for the preparation of annual studies (European Commission 2018, p. 2). Thus, the "CEPEJ methodology" is also used for the Scoreboard data (i.e. CEPEJ Questionnaires and Explanatory Note, data validation process, etc.) (European Commission 2018).

\section{FIGURE 1}

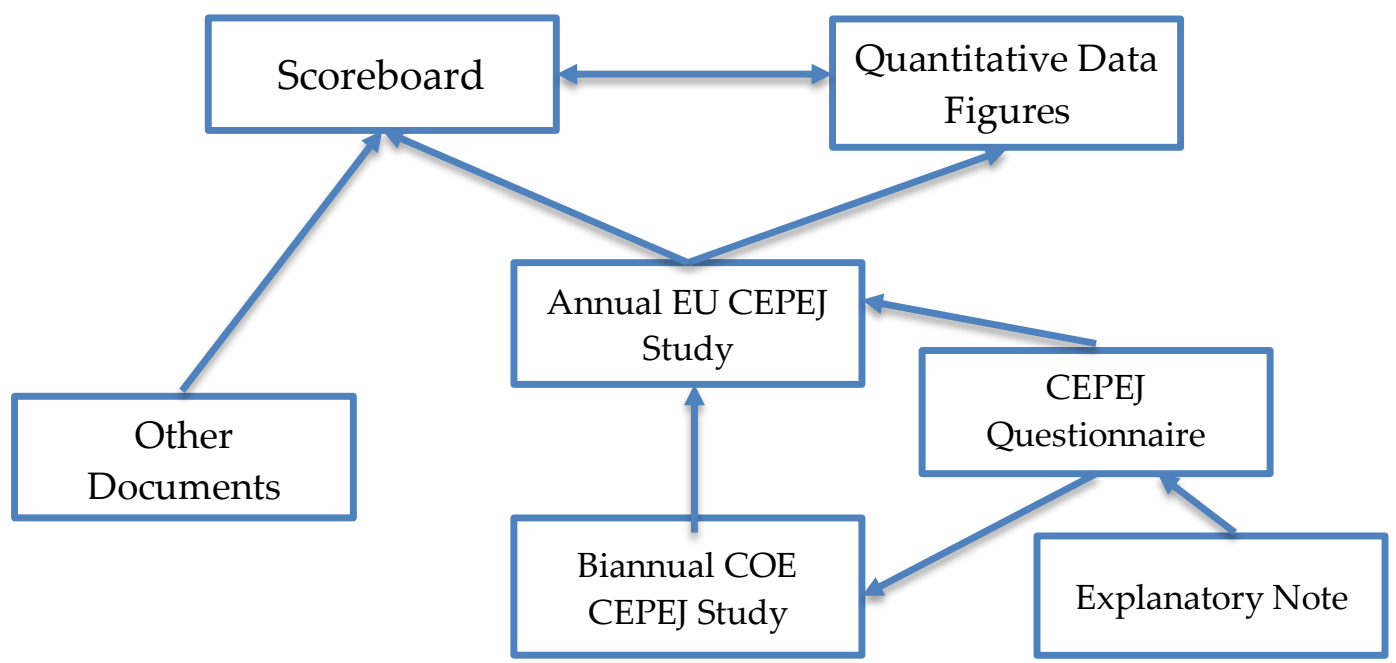

Figure 1. The interrelation between the documents forming the Scoreboard ecosystem (Onțanu et al. 2018, p. 502).

The CEPEJ is collecting data for the EU Justice Scoreboard related to national litigation based on a questionnaire. This questionnaire is filled-in by national correspondents of each Member State. Given known difficulties related to data gathering and aiming to provide good quality outcomes on the performance of justice systems the CEPEJ Evaluation working group, the Secretariat and the national correspondents collaborate seeking to improve the consistency of the data and the level of detail (see Fabri 2017). For this purpose, an Explanatory Note is periodically drafted and updated for assisting the "national correspondents and other persons entrusted with replying to the questions" (see for example, CEPEJ 2015a). This is to ensure that the "concepts are addressed according to a common understanding" (Fabri 2017). Given the particularities of national systems and data gathered or that can be retrieved from national statistics, the replies to CEPEJ questionnaires on the number of cases are often accompanied by additional comments and explanations that allow the reader to grasp important features of the type of cases counted by the reporting country. This contributes to a better interpretation of the results, although the particularities of the data and the additional qualifications are not always enough to secure an easy, straightforward comparison between the analysed justice systems. Furthermore, the CEPEJ cases categories used for the CEPEJ Report and Study were amended several times. This is the case at times also 
with statistics methodologies used by some Member State (e.g. definitions of national categories, changes in the aggregation of national categories to provide aggregated data to CEPEJ). These changes impair on the comparability of historical data series for different variables ${ }^{8}$ and makes the comparison of results of justice system more challenging to undertake in a meaningful way. Although the CEPEJ rule is to disregard data sets that do not appear sufficiently sound and/or accurate to merit publishing (CEPEJ 2016a, pp. 6-7; see also Dori 2015, p. 26), issues that are invisible at first sight continue to exist even for categories that are retained to be sound enough according to agreed standards. And, even though all these efforts are a welcomed development in supporting the national data collection and cooperation in improving justice results, the Scoreboard has limited powers to ensure the quality of the data gathered at the national level (see also Strelkov 2019, p. 23). At grassroot, the Member States remain responsible for the quality of the data and the figures transmitted. The existing process to collect data about national justice systems does not seem to be enough to adequately address the data comparability problems we discuss in the paper.

\subsection{Analysed data}

In order to evaluate the reliability and comparability of data concerning the caseload of national justice systems as provided by the European Commission in the Justice Scoreboard various interrelated evaluation documents are analysed. These are the 2018 edition of the Scoreboard (European Commission 2018), ${ }^{9}$ the Quantitative Data Figures for the 2018 edition of the Scoreboard (Quantitative Data Figures), ${ }^{10}$ the CEPEJ Study on the functioning of judicial systems in the EU Member States, Facts and Figures from the CEPEJ questionnaires 2010-2012-2013-2014-2015-2016 (Annual EU CEPEJ Study, CEPEJ 2018b), the Explanatory Note to the Scheme for Evaluating Judicial Systems (Explanatory Note, CEPEJ 2017), and the Studies №. 26 (CEPEJ 2018a).

The EU Justice Scoreboard and the Quantitative Data Figures rely on the data of the Annual EU CEPEJ Study for the variables regarding the number of cases (incoming, pending, and clearance rate). For the Annual EU CEPEJ Study, the CEPEJ collects the data on the functioning of the Member States judicial system in an annual report (CEPEJ 2018b). ${ }^{11}$ The report is drafted using a subset of the data collected for the Biannual COE CEPEJ Study for the even years, and a specific questionnaire ${ }^{12}$ filled in by the CEPEJ's EU Member States national correspondents for the even years (not covered by the Biannual CEPEJ evaluation). Similar to the Biannual COE CEPEJ Study, the Annual EU CEPEJ Study relies on the data analysis and comments sent by the Member States (Onţanu et al. 2018, p. 504). The CEPEJ processes and analyses the responses received. The data is collected and maintained in a database, which includes all the data collected

\footnotetext{
${ }^{8}$ For example, notices under Table 3.9.1 First instance courts: Caseload in the EU in 2014 (incoming cases per 100 inhabitants), CEPEJ Study based on the CEPEJ Reports.

9 The 2019 EU Justice Scoreboard was not used because the CEPEJ Study with EU Member States detailed data was not published for the that edition of the Scoreboard.

10 This is an additional document containing a selection of the Scoreboard graphs together with the quantitative data values used for drawing the graph.

11 The 2018 edition of the study is available at CEPEJ 2018b (part 1), as well as the countries' data fiches (CEPEJ 2018b part 2).

12 This is the Scheme for evaluating judicial systems used by the CEPEJ for the Biannual CEPEJ Study. See CEPEJ 2016b, p. 11.
} 
over the years. The variables used are common for both Biannual and Annual CEPEJ Studies (see the Explanatory Note to the Biannual COE CEPEJ Study).

\subsection{Selecting variables}

The consistency of the Scoreboard data for the chosen jurisdictions have been checked for the different case categories the evaluation uses, namely: "civil, commercial, administrative and other cases", "civil and commercial cases", and "administrative cases". The Scoreboard uses these variables as key elements to estimate the efficiency of the national proceedings.

The data consistency check is carried out in a three steps process comparing the values of the variables in the Quantitative Data Figures of the Scoreboard and the Annual EU CEPEJ Study, and between annual editions of the Annual EU CEPEJ Studies. The first step concerns the reliability of the historical data series: the consistency of the Quantitative Data Figures of the Scoreboard in Figures 4-6 corresponding to incoming cases, Figures 12-14 concerning the rate of resolved cases and Figures 15-17 regarding pending cases with the corresponding data in the Annual EU CEPEJ Study. This verification is useful for two reasons: first, because the Quantitative Data Figures variables rely on the results of the Annual EU CEPEJ Study, and, second, for checking whether the values of the variables are consistent between the two documents.

TABLE 1

\section{Quantitative Data Figures of the Scoreboard}

Figure 4, Number of incoming civil, commercial, Indicator 3: The performance of courts at all stages administrative and other cases (first instance/per 100 inhabitants).

\section{of the proceedings.}

Table 3.1.1.2 (2016, 2015, 2014, 2013, 2012, 2010) First instance courts, number of other than criminal cases in 2016, 2015, 2014, 2013, 2012, 2010 Incoming cases(Q91).

Figure 5, Number of incoming civil and commercial Table 3.1.1.2 (2016, 2015, 2014, 2013, 2012, 2010) litigious cases (first instance/per 100 inhabitants). ${ }^{13}$
First instance courts, number of other than criminal cases in 2016, 2015, 2014, 2013, 2012, 2010 Incoming cases (Q91).

Table 3.1.1.2 (2016, 2015, 2014, 2013, 2012, 2010) First instance courts, number of other than criminal cases in 2016, 2015, 2014, 2013, 2012, 2010 Incoming cases (Q91).

\footnotetext{
${ }^{13}$ Variable introduced for the first time in the 2018 EU Justice Scoreboard (European Commission 2018).
} 


\section{Quantitative Data Figures of the Scoreboard}

Figure 12, Rate of resolving civil, commercial, Table 3.2.1.1 (2016, 2015, 2014, 2013, 2012, 2010) administrative and other cases (first instance/in \%).

First instance courts: Clearance rate and disposition time in different type of other than criminal cases in 2016, 2015, 2014, 2013, 2012, 2010 (Q91).

Table 3.2.2.1 First instance courts, Variation of clearance rate and disposition time in different type of other than criminal cases between 20162015(Q91).

Table 3.10.4 First instance courts, Clearance rate (in \%) for total of first instance other than criminal cases in 2010, 2014, 2015 and 2016 (Q91).

Figure 13, Rate of resolving litigious civil and Table 3.2.1.1 (2016, 2015, 2014, 2013, 2012, 2010) commercial cases (first instance/in \%).

Figure 14, Rate of resolving administrative cases (first instance/in \%).

Figure 15, Number of civil, commercial, Indicator 3: The performance of courts at all stages administrative and other pending cases (first instance/per 100 inhabitants).
First instance courts, Clearance rate and disposition time in different type of other than criminal cases in 2016, 2015, 2014, 2013, 2012, 2010 (Q91).

Table 3.2.2.1 First instance courts, Variation of clearance rate and disposition time in different type of other than criminal cases between 2016-2015 (Q91).

Table 3.10.5 First instance courts, Clearance rate in (\%) for first instance civil and commercial litigious cases in 2010, 2014, 2015 and 2016 (Q91).

Table 3.2.1.1 (2016, 2015, 2014, 2013, 2012, 2010) First instance courts, Clearance rate and disposition time in different type of other than criminal cases in 2016, 2015, 2014, 2013, 2012, 2010 (Q91).

Table 3.2.2.1 First instance courts, Variation of clearance rate and disposition time in different type of other than criminal cases between 2016-2015 (Q91).

Table 3.10.6 First instance courts, Clearance rate in (\%) for first instance civil and commercial litigious cases in 2010, 2014, 2015 and 2016 (Q91).

of the proceedings.

Table 3.1.1.4 (2016, 2015, 2014, 2013, 2012, 2010) First instance courts, Number of other than criminal cases in 2016, 2015, 2014, 2013, 2012, 2010 - Pending cases on 31 December (Q91). 


\section{Quantitative Data Figures of the Scoreboard}

Figure 16, Number of litigious civil and commercial Indicator 3: The performance of courts at all stages pending cases

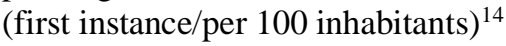

Figure 17, Number of administrative pending cases (first instance/per 100 inhabitants).

\section{Annual EU CEPEJ Study} of the proceedings.

Table 3.1.1.4 (2016, 2015, 2014, 2013, 2012, 2010) First instance courts, Number of other than criminal cases in 2016, 2015, 2014, 2013, 2012, 2010 - Pending cases on 31 December (Q91).

Indicator 3: The performance of courts at all stages of the proceedings.

Table 3.1.1.4 (2016, 2015, 2014, 2013, 2012, 2010) First instance courts, Number of other than criminal cases in 2016, 2015, 2014, 2013, 2012, 2010 - Pending cases on 31 December (Q91).

Table 1. Variables whose consistency is checked against each other across the Annual EU CEPEJ Study and Quantitative Data Figures of the Scoreboard (year 2018).

The second step of the verification assesses the yearly series of variables comparing the 2018 edition of the Annual EU CEPEJ Study with previous editions and explanations regarding the data provided by the Member States. This exercise seeks to identify whether there is any existing data variation. The 2018 Annual EU CEPEJ Study (as other editions of the study before this) contains a methodological disclaimer warning about data values that do not coincide (CEPEJ 2017, p. 6).

The last step consists in a cross-check between the CEPEJ case categories and the explanations provided by the selected Member States. The check is carried out in two steps. The first step analyses the evolution of the content of the CEPEJ case categories, comparing the 2013, 2015, and 2017 Explanatory Notes against each other. In the second step, the CEPEJ case categories are compared with the explanation provided by the French, Italian, and Romanian respondents in relation to the type of cases they included in each CEPEJ category. This allows the identification - for each of the three justice systems analysed - of the type of cases the national statistics include in the case categories, and in particular in the "civil, commercial, administrative and other cases", "civil and commercial cases (litigious and non-litigious)" and "administrative cases". This exercise reveals a clearer image of the comparability of the categories and their content, providing the means to assess the soundness, reliability, and comparability of the courts' caseload data.

\section{Evolution of the Scoreboard data}

Over the years, the Scoreboard evolved in two directions (Onţanu et al. 2018, p. 509). On the one hand, there are changes in the CEPEJ data, which are reflected almost automatically in the Scoreboard data. This leads over time to a series of invisible changes. On the other hand, the scope of the Scoreboard evolved from one edition to another. In its first version, the Scoreboard was intended as a "tool to support the efficiency of justice in EU Member States" (Velicogna 2013) and "to achieve more effective justice by providing objective, reliable and comparable data on the functioning of the justice

\footnotetext{
${ }^{14}$ No detailed data was included in the Quantitative Data Figures of the Scoreboard, but a table without absolute values is available in the 2018 EU Justice Scoreboard.
} 
systems of all Member States" (European Commission 2013, p. 3), while the most recent versions have taken a softer and more comprehensive approach.

Since the beginning, the Justice Scoreboard has systematically relied on the statistical data collected by the CEPEJ (Mohr and Contini 2014, p. 846). However, the modification in the operative definition of the data provided by the CEPEJ data series "have not always and consistently been indicated in the various editions of the Scoreboard and in the Quantitative Data Figures" (Onţanu et al. 2018, p. 511). In taking over the data from the CEPEJ Studies the first editions of the Scoreboard did away with the whole additional information that qualifies the CEPEJ charts data, as well as any caution notice about the comparability of the data (Mohr and Contini 2014, p. 846). The variables gain in a performative display of achievements of justice systems, and as remarked by Mohr and Contini to an "objectified rank" that appears to "becomes the only relevant information" repudiating "the very raison d'être of the CEPEJ study, which is to give an overview of the situation of the European judicial systems" (Mohr and Contini 2014, p. 847; vision also shared by Cappellina 2017, p. 69). The aim of the CEPEJ study is "not to rank the best judicial systems in Europe. This would be scientifically inaccurate and would not be a useful tool for the public policies of justice" (CEPEJ 2012, p. 9). A slight switch of approach in the Scoreboard came with the latest editions of the Scoreboard (for example, European Commission 2018, p. 2) that sought to soften the ranking approach perception and began including additional information and clarifications on the datasets, changes and national particularities that influence the results. For example, in the 2018 Scoreboard, the Figures 4-6 and 12-17 regarding the number of cases and clearance rates do contain some notices reporting changes in the methodology for data collection and categorisation. However, the same warning is not included in the corresponding Quantitative Data Figures charts. ${ }^{15}$ This change is undoubtedly a welcomed development, but the information and clarifications provided fall short of being sufficient to alert and prevent users from simplistically comparing results and ranking achievements. The omission of warnings regarding the quality of the data in the Quantitative Data Figures charts certainly maintains the impression that the data presented are fully comparable, although this is not the case based on other information contained in the Scoreboard and the CEPEJ Study warnings.

TABLE 2

\begin{tabular}{lllllll}
\hline Figure Caption & 2018 & 2017 & 2016 & 2015 & 2014 & 2013 \\
\hline $\begin{array}{l}\text { Number of incoming } \\
\text { cases }\end{array}$ & & & & & & \\
\hline $\begin{array}{l}\text { Number of incoming } \\
\text { civil, commercial, } \\
\text { administrative and other } \\
\text { cases per 100 } \\
\text { inhabitants }\end{array}$ & Figure 4 & Figure 2 & Figure 2 & Figure 2 & Not used & Not used \\
$\begin{array}{l}\text { Number of incoming } \\
\text { civil and commercial } \\
\text { litigious cases per 100 } \\
\text { inhabitants }\end{array}$ & Figure 5 & Figure 3 & Figure 3 & Figure 3 & Not used & Not used \\
\hline
\end{tabular}

${ }^{15}$ Similar situations were present also in other editions of the Scoreboard. See also Onțanu et al. 2018, p. 511. 


\begin{tabular}{|c|c|c|c|c|c|c|}
\hline Figure Caption & 2018 & 2017 & 2016 & 2015 & 2014 & 2013 \\
\hline $\begin{array}{l}\text { Number of incoming } \\
\text { administrative cases per } \\
100 \text { inhabitants }\end{array}$ & Figure 6 & Not used & Not used & Not used & Not used & Not used \\
\hline \multicolumn{7}{|l|}{ Clearance rate } \\
\hline $\begin{array}{l}\text { Rate of resolving civil, } \\
\text { commercial, } \\
\text { administrative and other } \\
\text { cases }\end{array}$ & Figure 12 & Figure 7 & Figure 7 & Figure 7 & Figure 5 & Figure $5^{16}$ \\
\hline $\begin{array}{l}\text { Rate of resolving civil } \\
\text { and commercial cases }\end{array}$ & Figure 13 & Figure 8 & Figure 8 & Figure 8 & Figure 6 & Figure 6 \\
\hline $\begin{array}{l}\text { Rate of resolving } \\
\text { administrative cases }\end{array}$ & Figure 14 & Figure 9 & Figure 9 & Figure 8 & Figure 7 & Figure 7 \\
\hline \multicolumn{7}{|l|}{ Pending cases } \\
\hline $\begin{array}{l}\text { Number of civil, } \\
\text { commercial, } \\
\text { administrative and other } \\
\text { pending cases }\end{array}$ & Figure 15 & Figure 10 & Figure 10 & Figure 10 & Figure 8 & Figure $8^{17}$ \\
\hline $\begin{array}{l}\text { Number of civil and } \\
\text { commercial pending } \\
\text { cases }\end{array}$ & Figure 16 & Figure 11 & Figure 11 & Figure 11 & Figure 9 & Figure 9 \\
\hline $\begin{array}{l}\text { Number of } \\
\text { administrative pending } \\
\text { cases }\end{array}$ & Figure 17 & Figure 12 & Figure 12 & Figure 12 & Figure 10 & Figure 10 \\
\hline
\end{tabular}

Table 2. Scoreboard evaluation figures correspondence regarding the number of cases (2013-2018).

The number of Scoreboard indicators describing the number of cases varied little over the years (see Table 2). The 2018 EU Scoreboard added the Number of incoming administrative cases per 100 inhabitants that was previously missing from other editions. This variable seems to have gained a stable place among the usual data to be included as the 2019 edition also contains it.

The Annual EU CEPEJ Study has accompanied each edition of the Scoreboard in providing additional details about the number presented by the Quantitative Data Figures. This does not seem to be the case anymore with the 2019 EU Justice Scoreboard. For the latest edition, the European Commission chose to present only the final quantitative data of the CEPEJ Study, excerpting from the report the numbers related to the presented variables, but without providing the interested reader with an opportunity to consult the details related to these data. This choice may seem as a sidestep that brings back the impression that the data presented are fully comparable and more consistent than the data used for previous Scoreboard editions. However, this is not always the case as discussed further in Section 6 of this paper.

\footnotetext{
${ }^{16}$ Rate of resolving non-criminal cases.

${ }_{17}$ Number of non-criminal pending cases.
} 


\section{Counting the cases: Assessing the caseload}

In order to determine the amount of litigation a justice system is dealing with during a particular period, typically one year, the amount of caseload needs to be determined. The caseload is the result of several variables, namely: the number of pending cases at the beginning of the year, the incoming cases during the year, the number of resolved cases, and the remaining pending cases at the end of the year. From an EU perspective, the Scoreboard chooses to offer the reader a partial image of the number of cases the Member States handle. The gaps in the data presented make the assessment of courts' caseload difficult from an internal perspective. At the same time, the readers are left with a need to identify necessary elements in additional documents from which the data was selected (i.e. Annual EU CEPEJ Study, Biannual COE CEPEJ Report).

The 2018 Scoreboard addresses the matter of courts caseload by choosing to rely on five indicators taken from the Annual EU CEPEJ Study: (1) the number of incoming civil, commercial, administrative and other cases (Figure 4); ${ }^{18}$ (2) number of incoming civil and commercial litigious cases (Figure 5); ${ }^{19}$ (3) number of incoming administrative cases (Figure 6);20 (4) number of civil, commercial, administrative and other pending cases (Figure 15); ${ }^{21}$ (4) number of litigious civil and commercial pending cases (Figure 16); ${ }^{22}$ and (5) number of administrative pending cases (Figure 17). Three other indicators are considered in the assessment of the caseload at national level. These are the clearance rates for the national courts: "rate of resolving civil, commercial, administrative and other cases" (Figure 12), "rate of resolving litigious civil and commercial cases" (Figure 13), and "rate of resolving administrative cases" (Figure 14). The clearance rate is the ratio between the number of resolved cases divided by the number of incoming cases, expressed in a percentage (CEPEJ 2018a, p. 238). This variable can indirectly provide information on the national caseload, but additional variables are necessary for this purpose, namely: the number of pending cases at the beginning of the year (1 January) and the number of resolved cases. This additional information can be found only in the Annual EU CEPEJ Study and the Biannual COE CEPEJ Study, but not in the Scoreboard and its Quantitative Data Figures. Thus, the use of a clearance rate variable is not able to fill in the gap for the missing quantitative variables. This certainly affects the ability of the Scoreboard to provide a complete image as to the effectiveness of justice systems, although a significant stride appears to have been put in by the European Commission to present complete and easy to read data on the functioning of Member States' justice systems.

\footnotetext{
18 Under the CEPEJ methodology, this category includes all civil and commercial litigious and non-litigious cases, non-litigious land and business registry cases, other registry cases, other non-litigious cases, administrative law cases and other non-criminal cases.

${ }^{19}$ Litigious civil and commercial cases concern disputes between parties, e.g. disputes regarding contracts, under the CEPEJ methodology.

${ }^{20}$ Introduced for the first time in the 2018 EU Justice Scoreboard (European Commission 2018).

${ }^{21}$ The Scoreboard charts concern pending cases at first instance at the end of the year (31 December) (European Commission 2018, p. 15).

${ }^{22}$ For the 2018 EU Justice Scoreboard, the Quantitative Data Figures (European Commission 2018) do not provide the quantitative data. It is not clear what was the reason for this change as previous editions contained the quantitative data for this chart as well.
} 
TABLE 3

\begin{tabular}{lcccc}
\hline & $\begin{array}{c}\text { Pending Incoming } \\
\mathbf{1}^{\text {st }} \\
\text { January } \\
\text { during the } \\
\text { year }\end{array}$ & $\begin{array}{c}\text { Decided } \\
\text { during the } \\
\text { year }\end{array}$ & $\begin{array}{c}\text { Pending 31 } \\
\text { December }\end{array}$ \\
\hline $\begin{array}{l}\text { Number civil, commercial, administrative and } \\
\text { other cases }\end{array}$ & Missing & Figure 4 & Missing & Figure 15 \\
$\begin{array}{l}\text { Number civil and commercial litigious cases } \\
\text { Number of administrative cases }\end{array}$ & Missing & Figure 5 & Missing & Figure 16 \\
\hline
\end{tabular}

Table 3. Categories of case charts contained in 2018 Scoreboard, in comparison with the variables available in the Annual EU CEPEJ Study.

Compared to the Annual EU CEPEJ Study, the Scoreboard uses only part of the variables that compose the national courts' annual caseload leaving some of the collected information aside from the main overall evaluation (i.e. the number of pending cases at January 1 as well as the number of cases resolved). ${ }^{23}$ This might leave the reader wondering if the clearance rate used in the Scoreboard (Figures 12-14) supplements or indirectly reflects on the variable chains that are left out of the annual caseload assessment. While a selection of data may help not overload the reader (Strelkov 2019, p. 23), the result is that critical data are missing. The Scoreboard evaluation provides no express explanation as to the choice of indicators beyond these being of common interest for the Member States and "relevant for the assessment of the quality, independence and efficiency of justice systems in all Member States" (European Commission 2018). At a closer look, all the variables analysed in this paper fall within the section of the Scoreboard related to the efficiency of justice systems. The importance of these variables may also be related to the Scoreboard providing information for the European Semester discussions regarding the improvement of the effectiveness of national judicial systems (European Commission 2018, p. 3). Following the Eurozone crisis, the Scoreboard became part of European Semester as a "soft governance" tool supporting the process of mitigating the consequences of the crisis by providing a systematic comparative overview of national justice systems (see also Strelkov 2019, p. 17). The European Semester is part of a dialogue between the European Commission and the Member States to support the coordination of national policies with EU goals and achieving structural reforms were needed. In this framework - relying on the Scoreboard results and bilateral dialogue between the European Commission and the individual Member States country-specific recommendations can be adopted to improve the efficiency of the national justice systems if retained necessary. Although the underlying objective is to assist the Member States to "achieve more effective justice" (European Commission 2016, p. 1), in looking at the incomplete image of the caseload and court activity the Scoreboard presents annually as absolute facts, some questions arise as to the potential consequences this truncated perspective has for the actually recommended measures. Are they reflecting the actual needs of the justice system they aim to support and improve?

${ }^{23}$ The number of cases pending on 1 January is one of the variables needed to understand the courts' caseload, together with the incoming cases, the resolved cases and the pending cases on 31 December. 
The number of cases pending on 1 January is part of the courts' caseload, together with the incoming cases, the resolved cases and the pending cases at the end of the year (Dubois et al. 2013, pp. 628-629, CEPEJ 2014, pp. 70-71, 2017, Questions 91 to 109, p. 19; 2018b, pp. 243-254). When answering the CEPEJ Questionnaires, the Member States respondents are asked to provide, for the reference year, the number of pending cases at the beginning of the year (pending cases on 1 January) and at the end of the year (pending case on 31 December), as well as incoming and resolved cases (CEPEJ 2017, Questions 91 to $109 ; 2018 b$, pp. 243-254).

An explanation on why the incoming cases per 100 inhabitants and pending cases on 31 December are used is not given. ${ }^{24}$ In practice, this choice limits the availability of information needed to grasp the caseload of the court systems. As mentioned earlier, the Scoreboard information is part of a broader discussion to support economic development by well-functioning justice systems (European Commission 2018), and a comparative perspective can be motivating and inspiring in improving its own national justice system. However, the additional data part of the bilateral dialogue within the frame of the European Semester and the analysis going on besides the Scoreboard is not always visible from outside. Thus, when looking at Member States caseload, coupling the clearance rates provided by the Scoreboard with the incoming cases and pending cases provides at least an indirect indication of the resolved cases and the effectiveness of the justice systems in handling their caseload.

Another element which hampers the assessment of the annual caseload on the basis of the Scoreboard data is the presence of significant discrepancies in the numbers of cases. These inconsistencies can be clearly identified by comparing the data on pending cases. A cross-check of the statistical data in the Quantitative Data Figures (Figures 15-17) with several tables in the Annual EU CEPEJ Study (Part 2) of the country fiches for France, Italy, and Romania shows that the the number of pending cases (Number of pending civil, commercial and administrative and other cases variable) on 31 December do not always match for both evaluations. For example, a small difference ( 0.1 between the Annual EU CEPEJ study compared to Quantitative Data Figures) could be identified for France and Romania in several years and a much more significant one for Italy in 2010 (0.8 additional difference in the Annual EU CEPEJ study compared to Quantitative Data Figures). While small differences might be due to approximation, this cannot be evinced from the available information and appears at least doubtful. Clear information is key for a proper understanding of the data and the results presented; furthermore, this would improve the comparability of the results. Thus, it is desirable that future editions of the Scoreboard would make the information presented on the number of pending cases clearer for each category of variables, and the values used between the various documents should match.

Furthermore, while the Scoreboard presents the number of pending cases only on 31 December (European Commission 2018, p. 15), the Annual EU CEPEJ Study provides the number of pending cases on 1 January and the number of pending cases on 31 December. Analysing the Annual EU CEPEJ Study (Part 2) data provided by France,

${ }^{24}$ This clarification is not included also in the Quantitative Data Figures charts, leaving the reader unsure over which set of data is used - pending at beginning or end of the year - although it can be surmised it is the later given the Scoreboard information and cross-checks with the values in the Annual EU CEPEJ Study. 
Italy and Romania allows the identification of several discrepancies between the number of pending cases on the first of January of a given year and the $31^{\text {st }}$ December of the previous year. This issue is further investigated in Section 6.2.

\section{Exploring the (in)consistencies of the Scoreboard and national case categories to improve comparability}

\subsection{Case definition and case typology}

Having a common understanding of what is or should be considered a case for the collection of data carried out for the CEPEJ and Scoreboard studies is a crucial element in making sure similar data is collected and presented between participating countries. In analysing the most advanced endeavours, issues of comparability appear to concern not only the measuring unit - "the case" - but also the type of cases that are assembled under the umbrella of well-established variables that are being analysed - "litigious civil (and commercial) cases", "general non-litigious civil (and commercial)", "administrative law" cases.

Until now the Annual EU CEPEJ Study (CEPEJ 2018b) and the 2018 Scoreboard have not included a specific definition about what should be considered a case. As a consequence, each Member State is left with its national definition. Sometimes the "case" definitions used in Member States' domestic statistics are implicit and could depend on technical aspects based on which cases and/or data are registered. Therefore, the definition of what is considered to be "a case" for the national statics is not always available in the published reports as the notion remains to a certain extent implicit and can vary over time due to various factors (e.g. change of court competence, delays in reporting cases status). ${ }^{25}$ For example, in Romania, the modifications of the Code of civil procedure on enforcement proceedings changed the status of the writ of execution (încuviințarea executării silite) a couple of times within the period of a few years. They were first counted as a court case to then become non-court procedures and later return to be court procedures. ${ }^{26}$ These changes have not been singled out in the datasets. Another example is Italy where the overload of the registry office led to different moments of delays in registering and updating the status of cases (e.g. between the date of the lodging or the closing of a case following judgment and the actual registration of the case within the court's case system as incoming or closed). Similar situations can also affect the number of incoming and pending or closed cases.

Furthermore, although the CEPEJ Studies have been developed as an analysis instrument to help countries have a comparative perspective into the functioning of other justice systems (Cappellina 2017, p. 69), Member States provide no steady information on the type of cases they include or are able to include in the CEPEJ established case categories. While common elements can be identified in the competence

\footnotetext{
${ }^{25}$ For example, France: "cause - Au sens large, désigne une affaire dont est saisi un juge", see Mots clés de la justice (available at http://www.justice.gouv.fr/mots-cles/mc c.html). The Council of the Magistracy Statistics in Romanian does not provide a definition of the "case" concept.

${ }^{26}$ Initial text of the code than modified by Law № 138/2014 in October 2014 that established that a judicial decision is no longer required to issue a writ of execution (încuviințarea executării silite) (Article 641 Code of civil procedure). Government Emergency Ordinance № 1/2016 modifies it giving it back to court to decide (see Article 666).
} 
of the courts of the three jurisdictions, existing differences cannot be ignored. How to fit these differences in the CEPEJ case categories is not always sufficiently clarified. The CEPEJ Explanatory Note definitions provide a reference. These definitions are periodically amended to "assist the national correspondents and other persons entrusted with replying to the questions" (CEPEJ 2013, 2015a, 2017) and to secure a shared understanding of the concepts and categories adopted. While this effort is laudable, it is a work in progress and the definitions of case categories are not exhaustive in the type of cases they include, leaving the Member States' and the national correspondents to fill in the gaps. For example, the definition of "litigious civil (and commercial) cases" and the "general non-litigious civil (and commercial)" evolved between the 2012-2014 cycle and the 2016-2018 one in what appears to be a refining and a clarification of the type of cases that are to be included in each of them. Although a welcomed development, this conceptual refining of the variables does not appear to be reflected in the numerical value of the presented data, beyond some recalculation of the number of "general nonlitigious civil (and commercial)" cases. This could depend on the fact that the data provided in the past already included these cases, and the definition used was not sufficiently precise in indicating it or by the fact that the change in the definition of the type of case was the result of an assessment of the type of cases the Member States generally include in the category of "litigious civil (and commercial)" cases (see also Onţanu et al. 2018, pp. 522-523). Another possible explanation could be that the Member States ignore the changes in the definitions, or they are unable to reassess the data according to the new definitions and keep following the previous ones. Yet another possibility is that, while the dataset is described as homogenous, in reality it is subject to various changes and the case types are not always consistently associated by the Member States to a specific category of cases but are aggregated differently over time. ${ }^{27}$ For example, from the 2012-2014 Explanatory Note it appears that the litigious enforcement procedures were not included in "cases relating to enforcement" category, but should have been included in the "litigious civil (and commercial) claims" (CEPEJ 2013, p. 16). In the 2016-2018 Explanatory Note (CEPEJ 2017) previous "cases related to enforcement" are now included in the category of "general civil (and commercial) nonlitigious cases". The separation of litigious and non-litigious enforcement cases and their inclusion within the corresponding litigious and non-litigious civil (and commercial) cases categories has not resulted in an amendment of the previously published results of the two categories. ${ }^{28}$ This raises some concerns as to whether all cases previously labelled as enforcement cases were actually non-litigious cases. How does this reflect in the Scoreboard? Based on the Annual EU CEPEJ Study data provided by the national contacts, the 2018 Scoreboard edition (as 2017 and 2016 editions) flags out changes that have been communicated in relation to the collection of data, reorganisation of courts, type of cases included in the CEPEJ categories and methodology used (e.g. Figures 4-6 and Figures 15-17, European Commission 2018, pp. 9-10 and 13-16). This is an important step allowing the identification of changes and to assess the consistency of the

\footnotetext{
${ }^{27}$ See on this also similar difficulties identified by earlier comparative research carried out by Ietswaart (1990).

${ }^{28}$ A similar situation has been identified in relation to "general non-litigious civil (and commercial) cases" (CEPEJ 2015a and 2017). On previous issues related to business registry cases in CEPEJ Report, see Onţanu et al. 2018, p. 523.
} 
data (Onțanu et al. 2018, p. 525), the way it is collected and aggregated, as these changes may affect the comparability of historical datasets within the analysed Member States as well as the compatibility of categories between various jurisdictions. Additionally, this can distort perception over the presented data and evolutions in the functioning of a justice system. However, the identification of the changes is not always sufficiently detailed, and does not fully answer to the need of having clear information on the type of cases that are selected by the Member States and included in each one of the case categories used by the Scoreboard. Additional action should be taken in this respect for future evaluations and data collection.

A step in this direction is also making clear what typology of cases the Member States include in the CEPEJ categories. ${ }^{29}$ This goes beyond the CEPEJ definition of what should be understood to be included in categories such as "litigious civil (and commercial) cases", "general non-litigious civil (and commercial) cases", "administrative law cases". At present, it is not clear whether the cases counted are only those types indicated as exampled in the definition of each category or there are also additional types of cases that are considered to fall under the indicated categories and included in the statistics collected (Ietswaart 1990, pp. 581-582). This raises questions concerning the comparability of the data among different judicial systems and "the soundness of the way the data is currently presented" (Onţanu et al. 2018, p. 524). This, in turn, can lead to distorted perceptions and effects on how a justice system is actually performing in terms of cases it handles, how it evolves over time, as some improvements in the quantitative data may be related to changes in the content of the category of cases that are used as variables rather than substantive causes. Such findings commend a careful handle and use of data resulting from the Scoreboard results, especially as this is subsequently employed in shaping public policies related to the rule of law and economic growth (see also Cappellina 2017, p. 69).

\subsection{Data inconsistency: Identifying the causes in the CEPEJ Report}

The Scoreboard data used to describe Member States courts caseload is sound and homogenous to the extent the data contained in the CEPEJ studies - the Annual EU CEPEJ Study and the Biannual COE CEPEJ Study - fulfil these characteristics. As a consequence, in order to identify potential inconsistencies in the data used a reversed analysis of the CEPEJ reports is required. In particular, we identified inconsistencies related to historical data series, categories of cases and status of the cases.

\section{Historical data series inconsistencies}

An element that leads to inconsistencies and limits the comparability of the historical datasets is related to the changes in the classification of cases. These changes in the classification at the national level limit the comparability of the historical datasets, and warnings in this sense are useful and desirable. As previously discussed, the Annual EU CEPEJ Study identifies modifications in the classification and data collection methodology. Lately, the Scoreboard is also briefly cautioning the reader on such

\footnotetext{
${ }^{29}$ At present, the Member States are not providing uniform or consistent information indicating the type of cases they include or are able to include in the CEPEJ established categories. On similar problematics with regard to cases that can be included in specific categories across different jurisdictions, see also Ietswaart 1990, pp. 571-593.
} 
changes. However, this does not often result in an amendment of the historical data series. This, in turn, leads the CEPEJ and Scoreboard evaluations to experience some difficulties in securing the comparability of data on the number of cases in the various categories used. As the analysis shows inconsistencies appear at different stages and concern the approximation and rounding up of data and partial use of indicators in the Scoreboard that do not reflect all the relevant variables related to the amount of litigation a judicial system handles in a year. As this affects the comparability as will be shown below, strong caution should be taken when using the absolute quantitative results.

The Annual EU CEPEJ Study Methodology section contains a disclaimer mentioning that annual data might differ across editions of the report because of updates and validations done by the Member States during subsequent periods; hence, data published in latest reports might not coincide with data published in previous reports (CEPEJ 2018b, p. 6). Furthermore, in verifying the data series between the 2018 Annual EU CEPEJ Study counties fiches and the 2018 Quantitative Data Figures some additional small differences often appear in the values of the overall number of incoming cases per 100 inhabitants and the overall number of pending cases per 100 inhabitants. This happens in all three studied Member States and often seems to be a consequence of the way the data are presented, summed and rounded up (the variation is of $+/-0,1$ ). However, the approximation process does not necessarily follow a unified approach in the solutions followed. Some values can be rounded up to the above number while others are not. The approaches also differ among the Member States. Romania and Italy register some exceptions in the rounding up as some values are above the $+/-0,1$. For Romania in 2016, the "number of incoming civil, commercial, administrative, and other case" is above +0,111 in the Annual EU CEPEJ values compared to the Quantitative Data Figures. For Italy, the pending cases for the period 2010-2013 contain more significant difference in the values between the Quantitative Data Figures (variations are between $+/-0.5$ to 0.8 ). In the 2018 edition of the Scoreboard only the 2010 inconsistency for Italy is still visible in the "number of pending civil, commercial and administrative and other cases". This can create doubts as to the number of cases considered and raises the question of the soundness of the data because the variations of the results for the same period are more significant between the different studies.

TABLE 4

\begin{tabular}{lcccc}
\hline & $\begin{array}{l}\text { 31 Dec. 2012- } \\
\text { 1 Jan. 2013 }\end{array}$ & $\begin{array}{c}\text { 31 Dec. 2013- } \\
\text { 1 Jan. 2014 }\end{array}$ & $\begin{array}{c}\text { 31 Dec. 2014- } \\
\text { 1 Jan. 2015 }\end{array}$ & $\begin{array}{c}\text { 31 Dec. 2015- } \\
\text { 1 Jan. 2016 }\end{array}$ \\
\hline \multicolumn{1}{c}{ France } & & & & \\
\hline $\begin{array}{l}\text { Civil (and } \\
\text { commercial) } \\
\text { litigious cases }\end{array}$ & Consistent & Consistent & Consistent & Consistent \\
$\begin{array}{l}\text { Civil (and } \\
\text { commercial) } \\
\text { non-litigious } \\
\text { cases }\end{array}$ & Consistent & Consistent & Consistent & Consistent \\
$\begin{array}{l}\text { Administrative } \\
\text { law cases }\end{array}$ & $\begin{array}{l}\text { Not consistent } \\
\text { (-7.566 cases) }\end{array}$ & $\begin{array}{l}\text { Not consistent } \\
\text { (+7.448 cases) }\end{array}$ & $\begin{array}{c}\text { Not consistent } \\
\text { (+1506 cases) }\end{array}$ & $\begin{array}{c}\text { Not consistent } \\
\text { (+864 cases) }\end{array}$ \\
\hline
\end{tabular}




\begin{tabular}{|c|c|c|c|c|}
\hline & $\begin{array}{l}31 \text { Dec. 2012- } \\
1 \text { Jan. } 2013\end{array}$ & $\begin{array}{l}31 \text { Dec. 2013- } \\
1 \text { Jan. } 2014\end{array}$ & $\begin{array}{l}31 \text { Dec. 2014- } \\
1 \text { Jan. } 2015\end{array}$ & $\begin{array}{l}31 \text { Dec. 2015- } \\
1 \text { Jan. } 2016\end{array}$ \\
\hline \multicolumn{5}{|l|}{ Italy } \\
\hline $\begin{array}{l}\text { Total other } \\
\text { than criminal } \\
\text { law cases }\end{array}$ & $\begin{array}{l}\text { Not consistent } \\
(+130.443 \text { cases })\end{array}$ & $\begin{array}{l}\text { Not consistent } \\
\text { (+376.768 cases })\end{array}$ & $\begin{array}{l}\text { Not consistent } \\
(+107.036 \text { cases })\end{array}$ & $\begin{array}{l}\text { Not consistent } \\
\text { (+30.054 cases) }\end{array}$ \\
\hline $\begin{array}{l}\text { Civil (and } \\
\text { commercial) } \\
\text { litigious cases }\end{array}$ & $\begin{array}{c}\text { Not consistent } \\
(+137.268 \text { cases })\end{array}$ & $\begin{array}{l}\text { Not consistent } \\
(-91.830 \text { cases })\end{array}$ & $\begin{array}{c}\text { Not consistent } \\
(+229.816 \text { cases })\end{array}$ & $\begin{array}{l}\text { Not consistent } \\
(+10.052 \text { cases })\end{array}$ \\
\hline $\begin{array}{l}\text { Civil (and } \\
\text { commercial) } \\
\text { non-litigious } \\
\text { cases }\end{array}$ & $\begin{array}{l}\text { Not consistent } \\
(-6.819 \text { cases })\end{array}$ & $\begin{array}{l}\text { Not consistent } \\
(+170.378 \text { cases })\end{array}$ & $\begin{array}{l}\text { Not consistent } \\
(-123.269 \text { cases })\end{array}$ & $\begin{array}{l}\text { Not consistent } \\
\text { (+21.601 cases) }\end{array}$ \\
\hline \multirow[t]{2}{*}{$\begin{array}{l}\text { Administrative } \\
\text { law cases }\end{array}$} & $\begin{array}{l}\text { Not consistent } \\
(-1.168 \text { cases })\end{array}$ & $\begin{array}{l}\text { Not consistent } \\
(+4.472 \text { cases })\end{array}$ & $\begin{array}{l}\text { Not consistent } \\
\text { (+489 cases })\end{array}$ & $\begin{array}{c}\text { Not consistent } \\
\text { (-599 cases) }\end{array}$ \\
\hline & $\begin{array}{l}31 \text { Dec. 2012- } \\
1 \text { Jan. } 2013\end{array}$ & $\begin{array}{l}31 \text { Dec. 2013- } \\
1 \text { Jan. } 2014\end{array}$ & $\begin{array}{l}31 \text { Dec. 2014- } \\
1 \text { Jan. } 2015\end{array}$ & $\begin{array}{l}31 \text { Dec. 2015- } \\
1 \text { Jan. } 2016\end{array}$ \\
\hline \multicolumn{5}{|l|}{ Romania } \\
\hline $\begin{array}{l}\text { Total other } \\
\text { than criminal } \\
\text { law cases }\end{array}$ & Consistent & $\begin{array}{r}\text { Not consistent } \\
\text { (+301.347 cases })\end{array}$ & $\begin{array}{l}\text { Not consistent } \\
\text { (-3.431 cases) }\end{array}$ & $\begin{array}{l}\text { Not consistent } \\
(+3.913 \text { cases })\end{array}$ \\
\hline $\begin{array}{l}\text { Civil (and } \\
\text { commercial) } \\
\text { litigious cases }\end{array}$ & Consistent & $\begin{array}{r}\text { Not consistent } \\
\text { (+316.420 cases })\end{array}$ & Consistent & Consistent \\
\hline $\begin{array}{l}\text { Civil (and } \\
\text { commercial) } \\
\text { non-litigious } \\
\text { cases }\end{array}$ & Consistent & $\begin{array}{l}\text { Not consistent } \\
\text { (-54.899 cases) }\end{array}$ & $\begin{array}{l}\text { Not consistent } \\
\text { (-8.981 cases) }\end{array}$ & $\begin{array}{l}\text { Not consistent } \\
\text { (-8.701 cases) }\end{array}$ \\
\hline $\begin{array}{l}\text { Administrative } \\
\text { law cases }\end{array}$ & Consistent & $\begin{array}{l}\text { Not consistent } \\
(+35.409 \text { cases })\end{array}$ & Consistent & Consistent \\
\hline
\end{tabular}

Table 4. Consistency of data regarding the pending court cases at 31 December compared to 1 January that next year.

Another point of inconsistency for the data series concerns the pending cases in the 2018 Annual EU CEPEJ Study country fiches. The study uses two types of pending cases: namely, "Pending cases on 31 December" and "Pending cases on 1 January" for each of the case category assessed (e.g. total of other than criminal cases; civil (and commercial) litigious and non-litigious cases; registry cases; administrative cases, etc.). In checking the French, Italian and Romanian datasets for the following periods: 31 December 20121 January 2013 and 31 December 2013-1 January 2014, 31 December 2014-1 January 2015, and 31 December 2015-1 January 2016 significant inconsistencies emerge as revealed by Table 4. The systematic differences between the "Pending cases on 31 December" and "Pending cases on 1 January" of the next year are considerable (i.e. sometimes hundreds of thousands of cases differences between 31 December and 1 January). The causes of these discrepancies are not always and consistently indicated in the country fiches or the explanations included in the Annual EU CEPEJ Study. From the analysed jurisdictions, some information is given for Italy and Romania. For example, for Italy, the statistics regarding the caseload at the end of 2013 indicate they can contain some "anomalies" 
due to the geographical reorganisation of courts between the second half of 2013 and the beginning of 2014 (CEPEJ 2018b, p. 293). The reorganisation led to the closing down of almost 1000 courts (ibidem). In Romania, the existing discrepancies between the number of pending cases on 31 December 2013 and 1 January 2014 can be related to a change in the data collection, as a result of new definitions for the fields "stocks" and "closed" and the moment a case is considered "closed". ${ }^{30}$ The significant differences between the two categories create doubts as to the consistency of the data sent by the national contacts and the content of the cases categories. Consequently, this affects the soundness of the data used by the Scoreboard on pending cases (Figures 15-17).

The explanation offered by the Member States in the Annual EU CEPEJ Studies is broad (even if often still insufficient), but it is undoubtedly useful to be read together with the absolute values presented by the Scoreboard charts. ${ }^{31}$ Such combined reading allows an understanding of the data in its systemic context which is much more valuable when reforms and policies are to rely on this data. Furthermore, this explains some of the differences existing between the justice systems of the Member States.

Inconsistencies related to the categories of cases

As previously remarked in Section 6.1, it is not clear how the Member States aggregate the data regarding the type of cases required by the case categories of the Biannual COE CEPEJ Study and Annual EU CEPEJ Study. The reasons behind continuing inconsistencies among the type of cases included in the CEPEJ case category or flagged by the Member States are not explicitly addressed by the studies. Having a clear understanding about the reasons of these limitations and differences in what is being included in each category and how data is collected at the national level can be a first step in considering solutions that can improve the coherence and quality of the data. This can lead to data from the same Member State or from different Member States that are not equivalent and cannot be directly compared against each other to be put together in the same categories of the Scoreboard without sufficient cautions being undertaken. Additionally, without cautioning the reader this cannot understand and consider the differences and limitations of the exercise that ultimately aims to support the quality of justice and economic activities within the internal market.

The analysis carried out reveals that inconsistencies in the categories of cases used by the CEPEJ and the Scoreboard exist not only between Member States data, but that this can be the case also for a Member State's historical data series concerning certain categories of cases. For example, the explanations the French, Italian, and Romanian national contacts provide about the typology of national cases included in the CEPEJ case categories and taken over by the Scoreboard are often not exhaustively clarified. Furthermore, at times such clarifications are included only in some editions of the reports and do not refer to modifications in the type of cases computed within a certain category. In taking the explanations provided by the national contact point and looking

\footnotetext{
${ }^{30}$ According to the explanation provided by the Romanian CEPEJ contact, a case is considered to be "closed" "only when the final decision, including its reasoning, is drafted, signed and communicated to the parties", and for this reason the number of pending cases on 31 December 2013 cannot be identical to the number of pending cases on 1 January 2014 (CEPEJ 2016b, p. 279).

${ }^{31}$ See for example Italy and the explanation it provides about the changes made in 2013 for the classification of civil cases influencing the split between the litigious and non-litigious cases (CEPEJ 2014, 2015b).
} 
more closely at the data France, Italy, and Romania are reporting in the "civil (and commercial) non-litigious cases" (Table 5 below) the differences between analysed systems and the comparability of the same data category becomes concrete. Such diversity of data can appear disturbing when seeking to get a good grasp as to how justice systems in the EU function in a specific area; and these are not the only inconsistencies that the users of the data should consider.

TABLE 5

\begin{tabular}{|c|c|}
\hline $\begin{array}{l}\text { Civil (and commercial) non-litigious cases for } 2016 \text { in } \\
\text { Annual CEPEJ Study (2018) }\end{array}$ & Member State \\
\hline Divorces by mutual consent & $\mathrm{FR}, \mathrm{IT}^{32}, \mathrm{RO}$ \\
\hline Legal separation & FR, IT \\
\hline Change in matrimonial regime & FR \\
\hline Child custody demands & FR \\
\hline Adoption & FR, $\mathrm{RO}^{33}$ \\
\hline Medically assisted procreation & FR \\
\hline Incapacity of a Minor & $\mathrm{FR}, \mathrm{IT}^{34}, \mathrm{RO}$ \\
\hline Inheritances & $\mathrm{FR}, \mathrm{IT}^{35}$ \\
\hline Compensation for violation of privacy & FR \\
\hline Change of surname & FR \\
\hline Marital status & FR \\
\hline Nationality & FR \\
\hline Functioning of a grouping & FR \\
\hline Disciplining of notaries and ministerial officers & FR \\
\hline Non-litigious enforcement cases & $\mathrm{FR}, \mathrm{IT}^{36}, \mathrm{RO}^{37}$ \\
\hline Guardianship and trusteeship & IT \\
\hline Uncontested payment orders & $\mathrm{IT}^{38}$ \\
\hline Technical appraisals & $\mathrm{IT}^{39}$ \\
\hline Granting of legal personality & RO \\
\hline Modification of the constitutive acts of legal persons & RO \\
\hline
\end{tabular}

32 The "uncontested divorces" indicated in this category since 2014 by Italy appears to correspond to the previous "divorces by mutual consent".

${ }^{3}$ Possibly this could be included in the broader indicated category "other non-litigious requests according to the Civil Procedure Code and the Civil Code (civil, litigation with professionals, minors and family)".

${ }^{34}$ This category might be the equivalent of the Italian category "protective measures for underaged".

${ }^{35}$ The "hereditament" cases indicated in the "civil (and commercial) non-litigious cases" since 2014 might concern "inheritances cases", but this cannot be verified on the basis of the CEPEJ Study explanations provided by Member States.

${ }^{36}$ Included based on the statistical data presented concerning the 2010-2013 datasets though not expressly indicated by the Italian national contact for CEPEJ. In the 2016 CEPEJ Study the enforcement cases have been included in the "other" category of cases.

${ }^{37}$ Included on the basis of statistical data presented with regard to the 2010-2013 datasets although not expressly indicated by the Romanian contact for CEPEJ in the 2016 CEPEJ study.

${ }^{38}$ Since 2014 included in the "civil (and commercial) non-litigious cases".

${ }^{39}$ Since 2014 included in the "civil (and commercial) non-litigious cases". 
Civil (and commercial) non-litigious cases for 2016 in Annual CEPEJ Study (2018)

Requests related to unions

Other non-litigious requests according to the Civil Procedure Code and the Civil Code (civil, litigation with professionals, minors and family)

Etc.

\section{Member State}

$\mathrm{RO}$

$\mathrm{RO}$

IT

Table 5. Types of case categories included by France, Italy and Romania in the CEPEJ civil (and commercial) non-litigious cases (source of data: CEPEJ 2018b).

Further national differences appear to affect the content of the data within the established categories. In looking at the same category of data - "civil and commercial non-litigious cases" - for the analysed jurisdictions over various editions of the Annual EU CEPEJ Studies, other inconsistencies and structural limitations emerge. From the available data, it is not clear whether this situation is created by the way the cases are registered and collected, the details of the information included in the registration of the case within the courts' systems, or whether there are additional reasons such as the respondents' perceptions or interpretation of the questions based on which the Annual EU CEPEJ Study data is gathered. For example, in the 2016 edition of the Annual EU CEPEJ Study Italy mentions that for 2010, 2012 and 2013 the category of "civil and commercial non-litigious cases" contains the same typology of cases: namely, separation and divorce by mutual consent, interdiction and incapacitation, protective measures for underage, guardianship and trusteeship, etc. From 2014 evaluation, the category also includes uncontested payment orders, uncontested divorces, technical appraisals, judicial interdiction and incapacitation, and hereditament (CEPEJ 2016b, p. 277). The "etc." in Table 5 remains unclear as to what type of cases it covers and whether the newer addition was part of the previous "etc.". However, the analysis shows that from 2014 onwards the combination of cases in the same category contains significant differences in Italy. This affects the comparability of the data within the same Member State, let aside across jurisdictions, even similar ones like France and Romania. Having an exhaustive list of the typology of cases included in a CEPEJ category would be a more helpful approach when it comes to the comparability of the data across jurisdictions (see also Onțanu et al. 2018, p. 529). France appears to be an example in this regard. According to the 2018 and 2016 Annual EU CEPEJ Studies, the French "non-litigious civil cases" include: divorces by mutual consent, legal/judicial separation, change in matrimonial regime, child custody demands/requests relating to parental authority, adoption, medically assisted procreation, the incapacity of a minor, inheritances, compensation for violation of privacy, change of surname, marital status, nationality, the functioning of a grouping and the disciplining of notaries and ministerial officers (CEPEJ 2018b, p. 286). In 2014 the "non-litigious enforcement cases" have been included in the "non-litigious civil (and commercial) cases" category in France.

In situations such as the one analysed the comparability of data is more a desirable achievement than actual reality. This reinforces the conviction that the comparability cannot be taken for granted. Improvements should be considered for future evaluations. Improvements will certainly need to consider the present limitations that are due to the way the cases are registered and collected, the level of detail the information includes in the registration of the case within the courts' systems, and the differences in domestic 
approaches towards what would be considered a litigious or non-litigious case, or whether certain requests are dealt with by administrative authorities or the courts. All these differences and inconsistencies in the datasets affect the coherence and the quality of the data. Hence, Member States data that are not equivalent are directly compared against each other in the Scoreboard without sufficient cautions being taken to underline the differences and limitations of the exercise.

\section{Inconsistencies related to the nature of a case}

As seen so far information concerning specific types of cases and their inclusion in a category or other of the Annual EU CEPEJ Study cannot be taken for granted. National differences continue to exist even when commonly agreed categories are used, and these differences might not be immediately visible to the reader based on charts information. However, the content of the various case categories is relevant for the performance of a justice system in various areas such as economic activities within the internal market, businesses, individual freedoms, administrative procedures, etc. and results cannot be considered to be interchangeable across categories. Based on the punctual information provided by the Member States on the type of cases they count for the CEPEJ case categories the inconsistencies in datasets across various jurisdictions can be related to the legal nature of particular cases. The legal nature of the case - meaning whether a specific claim is an administrative, civil and/or commercial, litigious or non-litigious - is established by domestic legislation or, even courts' practices (see on this Ietswaart 1990, pp. 581-582). An example is the way the cases of interdiction and incapacitation are categorised in France and Italy. In France, at least part of these cases are handled and counted as civil litigious cases. According to the explanation of the French CEPEJ contact, since 2014 the cases regarding persons in psychiatric care are counted as litigious civil cases. Differently, in Italy, the cases of interdiction and incapacitation are counted in the category "civil (and commercial) non-litigious cases" (CEPEJ 2016b, pp. 275-277, $2018 b$, p. 293). Therefore, what would be relevant information in a specific field is contained in two categories of cases that would not usually be directly compared or considered in relation to each other, namely: "civil (and commercial) cases" in one Member State against "civil (and commercial) non-litigious cases" in another.

\section{Inconsistencies related to the status of a case}

The status of a case is indicative of the number of cases a national justice system is dealing within a given period. The status of a case according to the CEPEJ categories can be "incoming", "pending" or "resolved". Inconsistencies appear to be mainly related to "pending" and "resolved" cases. This status depends on the national legislation. Therefore, there are differences across the Member States in what is considered to be a "pending" or a "resolved" case. Furthermore, such differences can appear even within the same legal system, if domestic legislation was amended over the years. Such differences between the two indicators can be problematic from an internal perspective. This is even more so for the Scoreboard that relies only on one of these indicators, the number of pending cases on 31 December for the evaluation of the efficiency Member States' justice systems. This can lead to additional distortions in the way the data are interpreted and used. An example of such chance can be seen in the data about Romania (see also Historical data series inconsistencies above). The CEPEJ Study clarifications reveal an amendment of the national norms regarding the registration of cases between the 
number of registered pending cases at 31 December and 1 January of the following year. According to Decision No. 46/2012 of the Superior Council of Magistracy amending the definition of the indicators of the court registration system, a case will be considered "closed" only when "the final decision, including its reasoning, is drafted, signed and communicated to the parties" (CEPEJ 2016b, p. 279). Thus, since 2014 there is a discrepancy between the two variables as indicated in Table 4. For France and Italy, it is not clear why such inconsistency exists between the pending number of cases on 31 December and 1 January of the following year, or why for certain categories the statistical data is consistent while for others this is not the case.

The national approach to consider a case "closed" - therefore, no more pending influences the effectiveness of a justice system and the time needed to resolve specific type of case. This certainly affects and leverages the results of a Member State justice system in the Scoreboard charts, and, subsequently, potential policy developments as part of the European Semester.

\subsection{Consequences of inconsistencies in case categories}

As discussed in Section 6.2, the way various types of national cases are registered and counted in a certain national and/or CEPEJ category of cases, the nature of the cases according to domestic legislation, and their status at a specific moment in time can have important implications for the number of cases a justice system declares to handle within a given timeframe and the results it can present in dedicated reports (i.e. length of judicial proceedings and clearance rate). Such continuing inconsistencies and discrepancies between CEPEJ datasets can create more distortions of data interpretation and comparability between the Member States justice systems when taken over by other evaluations such as the Scoreboard. Although unintentional, the use of existing data for developing policies and furthering reforms can snowball the effect of inconsistencies that do not reflect the reality of national justice systems. This becomes particularly important when these results containing inconsistencies and discrepancies contribute to the country's judicial systems' assessment and recommendations directed at justice improvements as part of the European Semester.

For example, a case regarding an opposition to administrative sanctions such as traffic fines is an administrative case in France and Romania (CEPEJ 2015b, p. 131, 2018b, p. 293), ${ }^{40}$ but a civil case in Italy (CEPEJ 2018b, p. 293). According to the explanations provided by the Italian Ministry of Justice for the 2018 and previous editions of the Annual CEPEJ Study, the introduction of a court fee for oppositions to administrative sanctions such as this resulted in a significant drop in the number of incoming cases. This further led to an improvement of the clearance rate (CEPEJ 2018b, p. 293). Hence, in comparing the clearance rate between the analysed countries, the improvements may be related to other factors (e.g. court fees and barriers to access to justice) rather than an actual improvement of the effectiveness of court activity. ${ }^{41}$ Although the actions taken

\footnotetext{
${ }^{40}$ For traffic offences in Romania, see Government Ordinance No. 2/2012 regarding the legal regime of contraventions.

${ }^{41}$ In Italy, a court fee is due to oppose an administrative act. This requirement was included in 2010 and influenced the number of incoming cases (Decree of the President of the Republic № 115/30 May 2012). In Romania, a court fee for contesting traffic fees as administrative acts was introduced in 2013 (Art. 19
} 
by Italy and Romania appear similar (e.g. introducing court fees) it would be difficult to compare the results in this area between the two countries, or at least this would be counterintuitive at first hand as the cases would be counted for different CEPEJ categories. Subsequently, the results are not comparable, or they can be compared only in carefully selected cases or relatively comparable categories but making sure that warnings and data tunings are included. Such examples prove one more time that the volume of cases is not absolute. Additional research would be necessary to weight the impact of the errors identified and to better map the case categories used in the various Member States in order to reduce such errors and make the use of data sounder in a comparative format.

\subsection{Possible solutions for identified inconsistencies}

In addressing data inconsistencies and clarifying the information concerning the number of cases and the content of each category of cases, the European Commission could consider several options for improving the Scoreboard and avoiding perpetuating the same problematics across editions. Some of the identified issues can be addressed within a short timeframe. From an internal perspective, it would be desirable that the Scoreboard would use complete data series for addressing the court's caseload. This would make immediately visible to the reader certain implicit variables (i.e. number of resolved cases and number of pending cases on 1 January). This should be directly reflected in the Quantitative Data Figures. Then, it would be useful for the Quantitative Data Figures to include, below the charts, the same type of warnings the Scoreboard includes about particular data distortions, modifications in the collection of data methodologies for certain Member States or particular national situations that influence the results of the variables. Another development that could be easily achievable would be for the European Commission to publish an additional document to the Scoreboard. This should include all the additional information and clarifications necessary to explain the values and results of the datasets, giving the interested reader the full possibility of understanding and analysing the results of a particular justice system in terms of number of cases that it can handle and their typology as well as being able to make relevant comparisons across established categories among Member States. Only detailed and transparent information on the results can be useful to consider additional needs of courts systems and for potentially developing alternative dispute resolution means. Additionally, such comparisons can provide national justice systems, as well as the European Commission within the European Semester discussions on reforms, a solid ground to understand national achievements in their own context and contribute to upholding the European values (see also Strelkov 2019, p. 17). Data particularities also become more transparent and easier to explore by any interested party. Further, national results that are retained to be interesting for inspiring improvements in the other Member States can be extensively analysed and evaluated against domestic realities, and potential downsides avoided. Such approaches are particularly relevant when a functional comparison (see Zweigert and Kötz 1998, p. 34, Örücü 2012, p. 563) is needed given the diversity of national justice systems. Developments such as this can further maximise the importance of the Scoreboard and of its exercise aiming to provide a

Government Emergency Ordinance № 80/2013), but the contact point for Romania has not made any remarks in the evolution of caseload determined by this amendment in court fees. 
comprehensive and systematic collection of data concerning Member States' justice systems.

In a short to long timeframe, additional steps should be taken to clarify and address identified inconsistencies remaining in the Member States' historical data series contained in the Annual EU and Biannual CEPEJ Studies as well as in the information provided by Member States. For this purpose, coordinated or concerted measures are required between the Member States and the CEPEJ. This concerns mainly the improvement of the soundness of the statistical data and data series that can facilitate comparisons at national and European level. Also, each Member State should make clear and exhaustive the type of cases it includes in each of the CEPEJ categories. A transparent image of the type of cases that are included in a particular category can facilitate the understanding of the results, of the way a certain justice system performs and functions, and where particular actions for improving results are necessary (see also Onțanu et al. 2018, p. 535). Disaggregating cases registration data and using socioeconomic criteria that are recognisable in all Member States' legal systems - such as the object of litigation (e.g. torts, debt, housing etc.) - can improve the comparability of variables (see also Ietswaart 1990, pp. 589-590). In the medium to long term it would be desirable to acquire a clearer understanding of the typology of cases that are included in the CEPEJ categories. In this sense, consideration should be given to the possibility of carrying out more in-depth analysis of results in clusters of Member States that have a similar approach in terms of categories of cases. This could contribute to the comparability of the data.

\section{Concluding remarks}

Quantitative data on the courts' caseload is increasingly relevant in the justice administration discourse, impacting courts operational evaluation, budget allocation, and the overall evaluation of the justice systems performance. In Europe, in particular, the data provided by the EU Justice Scoreboard has been playing an increasing role in EU negotiations and is used for academic discussion analysing the functioning of justice systems. While the question of comparability of this data is often mentioned, this topic has remained marginal in the whole discourse which this data generates. At the same time, the data is increasingly used in the academic and political debate coupled with the CEPEJ data on which it is based, as the best source available at EU level.

To raise awareness on - and increase the understanding of - the issue, this paper analysed in detail some of the significant problems that affect the quantitative variables used to present the EU Member States courts caseload in the EU Justice Scoreboard. It is an issue which affects the data provided both in terms of quality and comparability.

The analysis has been carried out following a two prongs approach. On the one hand, we have explored the methodology behind the EU Justice Scoreboard data collection and analysis, its evolution over the years, and its consistency. On the other hand, we explored in-depth the comparability of case categories and data collected in France, Italy and Romania. The findings of this analysis suggest that extreme caution should be exercised in the use of court caseload indicators for comparative purposes among justice systems. The quality and soundness of the present data can hardly allow a political or legislative 
comparative discourse based on the amount of litigation each Member State is dealing with. This is made impossible by existing inconsistencies and comparability deficiencies.

The work carried out in the paper allowed to identify a number of sources of inconsistency, which can be used to improve the data collection. Actions that need to be taken include: improving the definition of case categories and working with Member States in order to better (and more homogeneously) match national definitions with the European ones; including the definition of the status of the case; providing detailed information on how national categories fit with the EU schema; and improving historical consistency.

Full or partial comparability of data regarding the cases a justice system receives, resolves, and remain pending across jurisdiction will be possible only if all factors that lead to inconsistencies, as identified by this paper, are set aside or isolated. Otherwise, results must be considered with great caution and any comparability on the existing datasets between the Member States must be addressed with care and in a broader framework that provides all the particular details that characterise the registered values.

\section{References}

Bencze, M., Kovács, Á., and Ződi, Z., 2017. The evaluation and development of the quality of justice in Hungary. In F. Contini, ed., Handle with care. Assessing and designing methods for evaluation and development of the quality of justice (HWC) (JUST/2015/JACC/AG/QUAL/8547) [online]. Available from: https://www.lut.fi/hwc [Accessed 21 September 2020].

Cappellina, B., 2017. Évaluer l'Administration de la Justice dans les Pays Européennes. Une Co-Construction entre l'Union Européenne et Conseil de l'Europe. Revue Française d'Administration Publique [online], 161(2017)1, 59-72. Available from: [Accessed 21 September 2020].

Contini, F., and Mohr, R., 2008. Judicial Evaluation: Traditions, Innovations and Proposals for Measuring the Quality of Court Performance. Saarbrücken: VDM.

Contini, F., ed., 2017. Handle with Care: Assessing and Designing Methods for Evaluation and Development of the Quality of Justice (HWC) (JUST/2015/JACC/AG/QUAL/8547) [online]. Available from: https://www.lut.fi/hwc [Accessed 21 September 2020].

Contini, F., Mohr, R., and Velicogna, M., 2014. Formula over function? From algorithms to values in judicial evaluation. From Algorithms to Values in Judicial Evaluation. Oñati Socio-Legal Series [online], 4(5). Available from: http://opo.iisj.net/index.php/osls/article/view/311/493 [Accessed 21 September 2020].

Contini, F., Onțanu, E.A., and Carnevalli, D., 2017. The common research methodology for the analysis of the quality of justice at national level. In: F. Contini, ed., Handle with Care: Assessing and Designing Methods for Evaluation and Development of the Quality of Justice (HWC) (JUST/2015/JACC/AG/QUAL/8547) [online]. Available from: https://www.lut.fi/hwc [Accessed 21 September 2020]. 
Dori, A., 2015. The EU Justice Scoreboard - Judicial Evaluation as a New Governance Tool. MPI Luxembourg Working Paper Series [online], 2. Available from: https://doi.org/10.2139/ssrn.2752571 [Accessed 21 September 2020].

Dubois, E., Schurrer, C., and Velicogna, M., 2013. The functioning of judicial systems and the situation of the economy in the European Union Member States, CEPEJ-CoE [online]. Report prepared for the European Commission (Directorate General JUSTICE), Strasbourg, 15 January. Available from:

https://issat.dcaf.ch/download/38802/577451/cepej_study_justice_scoreboard_en.p df [Accessed 21 September 2020].

European Commission for the Efficiency of Justice (CEPEJ), 2012. European judicial systems, edition 2012 (2010 data). Study № 18 [online]. Strasbourg: CEPEJ.

Available from: https://rm.coe.int/to-fausto-de-santis-president-of-the-cepej-from2007-to-2010-/16807882a2 [Accessed 21 September 2020].

European Commission for the Efficiency of Justice (CEPEJ), 2013. Explanatory Note to the Scheme for Evaluating Judicial Systems, 2012-2014 Cycle (CEPEJ(2012)13Rev) [online]. Strasbourg: CEPEJ, 23 May. Available from: https://rm.coe.int/16807476a3 [Accessed 21 September 2020].

European Commission for the Efficiency of Justice (CEPEJ), 2014. Study on the functioning of judicial systems in the EU Member States, Facts and figures from CEPEJ evaluation exercises, CEPEJ 2012-2014 (CEPEJ(2014)4 final). Strasbourg: CEPEJ.

European Commission for the Efficiency of Justice (CEPEJ), 2015a. Explanatory Note to the Scheme for Evaluating Judicial Systems, 2014-2016 Cycle (CEPEJ(2015)2) [online]. Strasbourg: CEPEJ, 2 June. Available from: https://rm.coe.int/16807474b8 [Accessed 21 September 2020].

European Commission for the Efficiency of Justice (CEPEJ), 2015b. Study on the functioning of judicial systems in the EU Member States. Facts and figures from the CEPEJ questionnaires 2010-2012-2013 (CEPEJ(2014) 17final (v2.0 - 16 feb. 2015)). Strasbourg: CEPEJ, 16 February.

European Commission for the Efficiency of Justice (CEPEJ), 2016a. Report on "European judicial systems - Edition 2016 (2014 data): efficiency and quality of justice", Study No 23 [online]. Strasbourg: CEPEJ. Available from: https://rm.coe.int/europeanjudicial-systems-efficiency-and-quality-of-justice-cepej-stud/1680786b58 [Accessed 21 September 2020].

European Commission for the Efficiency of Justice (CEPEJ), 2016b. Study on the functioning of judicial systems in the EU Member States, Facts and figures from the CEPEJ questionnaires 2010-2012-2013-2014, Part 1 (CEPEJ(2015)15Part1rev2). Strasbourg: CEPEJ, 14 March.

European Commission for the Efficiency of Justice (CEPEJ), 2017. Explanatory Note to the Scheme for Evaluating Judicial Systems, 2016-2018 Cycle (CEPEJ(2017)3rev1) [online]. Strasbourg: CEPEJ, 20 November. Available from: https://rm.coe.int/explanatory-note-to-the-scheme-for-evaluating-judicialsystems/1680767c02 [Accessed 21 September 2020]. 
European Commission for the Efficiency of Justice (CEPEJ), 2018a. Report on "European judicial systems. Efficiency and quality of justice", Study № 26 [online]. Strasbourg: CEPEJ. Available from: https://rm.coe.int/rapport-avec-couv-18-09-2018en/16808def9c [Accessed 21 September 2020].

European Commission for the Efficiency of Justice (CEPEJ), 2018b. Study on the functioning of judicial systems in the EU Member States: Facts and figures from the CEPEJ questionnaires 2010-2012-2013-2014-2015-2016 (CEPEJ(2017)12 rev) [online]. Study prepared under the authority of the Working Group on the evaluation of judicial systems (CEPEJ-GT-EVAL) for the attention of the European Commission (Directorate General Justice). Strasbourg: CEPEJ, 4-5 April. Available from: https://ec.europa.eu/info/sites/info/files/20180405 - eu scoreboard indicators.pdf (part 1) and https://ec.europa.eu/info/sites/info/files/20180404 eu scoreboard - country fiches.pdf (part 2) [Accessed 21 September 2020].

European Commission, 2013. The EU Justice Scoreboard, A tool to promote effective justice and growth. Communication from the Commission to the European Parliament, the Council, the European Central Bank, the European Economic and Social Committee and the Committee of the Regions (COM(2013) 160 final) [online]. Brussels, 27 March. Available from:

https://ec.europa.eu/info/sites/info/files/justice scoreboard 2013 en.pdf [Accessed 21 September 2020].

European Commission, 2016. Communication from the Commission to the European Parliament, the Council, the European Central Bank, the European Economic and Social Committee and the Committee of the Regions - The 2016 EU Justice Scoreboard (COM(2016) 199 final) [online]. Available from:

https://ec.europa.eu/info/sites/info/files/justice scoreboard 2016 en.pdf. [Accessed 21 September 2020].

European Commission, 2018. The 2018 EU Justice Scoreboard. Communication from the Commission to the European Parliament, the Council, the European Central Bank, the European Economic and Social Committee and the Committee of the Regions (COM(2018) 364 final) [online]. Luxembourg: Publications Office of the European Union. Available from: https://ec.europa.eu/info/sites/info/files/justice scoreboard 2018 en.pdf [Accessed 21 September 2020].

Fabri, M., 2017. Methodological issues in the comparative analysis of the number of judges, administrative personnel, and court performance collected by the Commission for the Efficiency of Justice of the Council of Europe. Oñati SocioLegal Series [online], 7(4), 616-639. Available from:

http://opo.iisj.net/index.php/osls/article/viewFile/876/1021 [Accessed 21 September 2020].

Fabri, M., and Langbroek, P.M., eds., 2000. The Challenge of Change for Judicial Systems: Developing a Public Administration Perspective. Amsterdam: IOS Press.

Ietswaart, H.F.P., 1990. The international comparison of courts caseloads: The experience of the European Working Group. Law \& Society Review [online], 24(2). Available from: https://doi.org/10.2307/3053697 [Accessed 21 September 2020]. 
Koeijers, E., 2005. Sharp increase in civil court cases. Centraal Bureau voor de Statistik (CBS) [online], 12 July. Available from: https://www.cbs.nl/en$\mathrm{gb} /$ news/2005/28/sharp-increase-in-civil-court-cases [Accessed 21 September 2020].

Lijphart, A., 1975. II. The comparable-cases strategy in comparative research. Comparative political studies [online], 8(2), 158-177. Available from: https://doi.org/10.1177/001041407500800203 [Accessed 21 September 2020].

Mohr, R., and Contini, F., 2014. Conflicts and Commonalities in Judicial Evaluation. Oñati Socio-Legal Series [online], 4(5). Available from: http://opo.iisj.net/index.php/osls/article/view/312 [Accessed 21 September 2020].

Onţanu, E.A., Velicogna, M., and Contini, F., 2018. How many cases? Assessing the comparability of EU Judicial datasets. Presented at the Conference Ius Dicere in a Globalized World XXIV Bi-Annual Colloquium of the Italian Association of Comparative Law (AIDC), Naples, 15-17 June 2017. In: C.A. d'Allessandro and C. Marchese, eds., Jus Dicere in a Globalised World (vol. 2). Rome: Tre-Press, 497-537.

Örücü, E., 2012. Methodology of comparative law. In: J. M. Smits, ed., Elgar Encyclopedia of Comparative Law. $2^{\text {nd }}$ ed. Cheltenham: Edward Elgar, 560-576.

Palumbo, G., et al., 2013. The Economics of Civil Justice. New Cross-Country Data and Empirics. OECD Economics Department Working Papers [online], no 1060 . Available from: http://dx.doi.org/10.1787/5k41w04ds6kf-en [Accessed 21 September 2020].

Pauliat, H., et al., 2017. The evaluation and development of the quality of justice in France. In: F. Contini, ed., Handle with Care: Assessing and Designing Methods for Evaluation and Development of the Quality of Justice (HWC) (JUST/2015/JACC/AG/QUAL/8547) [online]. Available from: https://www.lut.fi/hwc [Accessed 21 September 2020].

Pekkanen, P., Puolakka, T., and Pirttilä, T., 2017. The evaluation and development of the quality of justice in Finland. In: F. Contini, ed., Handle with Care: Assessing and Designing Methods for Evaluation and Development of the Quality of Justice (HWC) (JUST/2015/JACC/AG/QUAL/8547) [online]. Available from: https://www.lut.fi/hwc [Accessed 21 September 2020].

Strelkov, A., 2019. EU Justice Scoreboard: A New Policy Tool for "Deepening" European Integration? Journal of Contemporary European Studies [online], 27(1). Available from: https://doi.org/10.1080/14782804.2018.1534729 [Accessed 21 September 2020].

Stretton, H., 2013. The Political Sciences: General Principles of Selection in Social Science and History. Abingdon: Routledge.

Uzelac, A., 2012. Efficiency of European Justice Systems. The strength and weaknesses of CEPEJ evaluations. International Journal of Procedural Law, 1(1).

Velicogna, M., 2013. The EU Justice Scoreboard and the challenge of investigating the functioning of EU justice systems and their impact on the economy of the Member States. Paper presented at the XXVII Convegno annuale della Società Italiana di Scienza Politica (SISP), 12-14 September 2013, Firenze, Italy. 
Velicogna, M., 2015. Study on Council of Europe Member States Appeal and Supreme Courts' Lengths of Proceedings Edition 2015 (2006-2012 data) (CEPEJ(2015)7Rev) [online]. Strasbourg, 7 September. Available from: https://rm.coe.int/168074823b [Accessed 21 September 2020].

Velicogna, M., and Ng, G.Y., 2006. Legitimacy and Internet in the Judiciary: A Lesson from the Italian Courts' Website Experience. International Journal of Law and Information Technology, 14(3).

Zweigert, K., and Kötz, H., 1998. Introduction to Comparative Law. Trans.: T. Weir. $3^{\text {rd }}$ ed. Oxford: Clarendon Press. 